\title{
Thermodynamic stability versus kinetic lability of $\mathrm{ZnS}_{4}$ core
}

\author{
Delphine Picot, Gilles Ohanessian, Gilles Frison* \\ Laboratoire des Mécanismes Réactionnels, \\ Département de Chimie, Ecole Polytechnique and CNRS, \\ 91128 Palaiseau Cedex, France. \\ Fax: + $0033(0) 169334803$ \\ gilles.frison@polytechnique.org
}

\begin{abstract}
Density Functional Theory and post-Hartree Fock calculations reveal an unusual energy profile for $\mathrm{Zn}-\mathrm{S}$ and $\mathrm{Zn}-\mathrm{N}$ bond dissociation reactions in several $\mathrm{Zn}(\mathrm{SR})_{4}{ }^{2-}$ and $\mathrm{Zn}(\operatorname{Im})(\mathrm{SR})_{3}{ }^{-}$complexes. The $\mathrm{Zn}-\mathrm{S}$ bond dissociation in tetrathiolate dianions, which is highly exothermic in the gas phase, proceeds through a late transition state which can be rationalised on the basis of an avoided-crossing resulting from Coulomb repulsion between the anionic fragments and ligand-to-metal charge-transfer in the $\mathrm{Zn}(\mathrm{SR})_{4}{ }^{2-}$ complexes. When solvation models for water, DMSO or acetonitrile are included, some complexes become stable while others are metastable, so this constitutes the first theoretical model which is in full agreement with the experimental data for various $\mathrm{Zn}(\mathrm{SR})_{4}{ }^{2-}, \mathrm{Zn}(\mathrm{SR})_{3}{ }^{-}$and $\mathrm{Zn}(\mathrm{Im})(\mathrm{SR})_{3}{ }^{-}$ complexes. The analysis given here indicates that the $\mathrm{Zn}(\mathrm{Cys})_{4}$ and $\mathrm{Zn}(\mathrm{His})(\mathrm{Cys})_{3}$ cores of numerous proteins are metastable with respect to $\mathrm{Zn}-\mathrm{S}$ and $\mathrm{Zn}-\mathrm{N}$ bond dissociation respectively; this is consistent with the kinetic lability at the zinc-centres and illustrates that, in nature, thermodynamic stability is imparted upon the zinc cores by the protein environment.
\end{abstract}

Keywords: zinc, metalloproteins, bond energy, computational chemistry, S ligands 


\section{Introduction}

Zinc is an essential element in nature. Zinc-binding proteins, which constitute approximately $10 \%$ of the human proteome,${ }^{[1]}$ have disparate roles which range from the purely structural to catalysis $^{[2]}$ and can be classified into four distinct categories : "catalytic", "co-catalytic", "structural" and "interface". ${ }^{[3,4]}$ In these proteins, the sulfur, nitrogen and oxygen donors of cysteine, histidine and glutamate/aspartate residues ${ }^{[5-7]}$ bind tightly to zinc within a tetrahedral coordination environment that comprises either three amino acid residues and one water molecule or four amino acids. The most common coordination sphere for the zinc atom is $\mathrm{Cys}_{4}$, which is usually found in zinc fingers but also appears in others proteins like alcohol dehydrogenase and the ADA DNA repair proteins. ${ }^{[1,8,9]}$ Most natural $\mathrm{ZnCys}_{4}$ sites play an essentially structural role, wherein the zinc centre confers a tertiary structure that allows the protein to assume its proper biological function. The protein $\mathrm{Cys}_{4}$ cores bind zinc with high stability constants ${ }^{[10-14]}$ and calculations modelling such $\mathrm{ZnCys}_{4}$ sites confirm large binding energies. $^{[15-17]}$

The flexible coordination properties of the zinc cation are important with respect to its role in proteins. ${ }^{[18]}$ Whilst protein-bound zinc is normally four-coordinate and tetrahedral, the $\mathrm{Zn}^{2+}$ cation can accommodate four to six ligands in synthetic complexes ${ }^{[19-23]}$ or when microsolvated by small molecules. ${ }^{[24,25]}$ This flexibility of coordination number and geometry, which is likely to involve an entropic contribution, ${ }^{[26,27]}$ probably accounts for the catalytic activity of zinc. ${ }^{[28,29]}$ This also facilitates ligand exchange reactions. ${ }^{[30,31]}$ These are observed in metallothioneins ${ }^{[32,33]}$ and $\left[\mathrm{Zn}_{4}(\mathrm{SPh})_{10}\right]^{2-}$ cage clusters, ${ }^{[34,35]}$ both of which contain kinetically labile Zn-thiolate bonds. Ligand exchange has also been recently demonstrated in several mononuclear bioinorganic zinc complexes, ${ }^{[36-38]}$ a mononuclear $\mathrm{ZnCys}_{4}$ zinc finger $^{[39,}$ ${ }^{40]}$ and the dinuclear zinc site of the enzyme IMP-1 metallo- $\beta$-lactamase. ${ }^{[41]}$

The kinetic lability of structural $\mathrm{ZnCys}_{4}$ sites is surprising, given their high thermodynamic stability and the fact that model zinc complexes containing pyrazolyl and arylthiolate ligands show high zinc-thiolate bond energies. ${ }^{[42,43]}$ This area has been discussed in some detail and a number of earlier observations are pertinent. First, with respect to ligand exchange, it has been proposed that exchange may be initiated by an incoming metal ion ${ }^{[35,41,44-46]}$ or protonation of the zinc-bound thiolate; ${ }^{[47]}$ it has also been suggested that the metal coordination sphere influences the zinc-thiolate interaction energy. ${ }^{[48]}$ Second, it is known that the $\mathrm{ZnS}_{4}$ core is not sufficiently favourable in thermodynamic terms to allow the preparation of homoleptic 
tetrahedral zinc complexes containing 2,3,5,6-tetramethylbenzenethiolate ${ }^{[49]}$ or 1 adamantanethiolate ligands, ${ }^{[50]}$ and $\mathrm{Zn}(\mathrm{SR}){ }_{3}{ }^{-}$complexes are obtained instead. Steric bulk is clearly important in these cases, but it is noteworthy that the zinc coordination sphere can be completed by a smaller fourth ligand such 1-methylimidazole. ${ }^{[49]}$ Third, few mononuclear complexes having a $\left[\mathrm{ZnS}_{4}\right]^{2-}$ core have been structurally characterized ${ }^{[28]}$ and almost all of these are zinc tetraarylthiolates; ${ }^{[51-54]}$ zinc tetraalkylthiolates have only been obtained with bidentate ligands ${ }^{[55]}$ or within peptide frameworks. ${ }^{[10,12,56-58]}$ Fourth, total Zn-S binding energies are calculated to be higher in three-coordinated than four-coordinated zincthiolates. ${ }^{[15-17]}$ Finally, multiply charged gas phase ions, whether cationic or anionic, tend to effect charge separation by fragmentation (through "Coulomb explosion") or, only for polyanions, by electron loss. ${ }^{[59-61]}$ Given that the stability of the prototypical diatomic dication $\mathrm{He}_{2}{ }^{2+}$, discussed in Pauling's early studies, ${ }^{[62]}$ results from a metastable electronic ground state whose highly exothermic dissociation to monocation products is prevented by a significant kinetic barrier, it is reasonable to propose that a similar situation could be extend to the dianionic metal complexes discussed above.

In an attempt to reconcile the thermodynamic stability and kinetic lability of dianionic tetrathiolate zinc complexes, and to provide a coherent rationalisation for the disparate results above, a study of the dissociation of the zinc-thiolate bond in biomimetic complexes by $a b$ initio and DFT methods was undertaken. It is described here.

\section{Computational Methods}

Numerous calibration studies on computational methods have been published recently (see for example ref ${ }^{[63-69]}$ ) and several have been used to model zinc complexes. ${ }^{[70-78]}$ This plethora of computational tools, especially new density functionals, and their sometimes contradictory performance, makes it difficult to choose the best method for any given system. We thus decided to use a well established methodology, ${ }^{[79-82]}$ the GGA density functional BP86, ${ }^{[83-85]}$ to optimise all of our geometries. These geometry optimization calculations were accelerated using the Multipole Accelerated Resolution of Identity for J (MARI-J) approximation method, ${ }^{[86]}$ as implemented in Turbomole. ${ }^{[87]}$. Basis sets of split valence quality, labelled def2-SVP, ${ }^{[88,89]}$ and the associated auxiliary basis sets to fit Coulomb potentials, ${ }^{[90]}$ were employed in the geometry optimization for all atoms. The validity of our standard methods was confirmed recalculating representative compounds at more sophisticated levels (see the supporting information) and comparing the results at the different calculational levels. Small 
structural differences appeared, but these did not translate into significant energy differences at the higher levels of computation. ${ }^{[75]}$

Each stationary point was characterized by a frequency analysis and found to show the correct number of negative eigenvalues (zero for a local minimum and one for a transition state). The calculated frequencies were scaled by a factor of $0.9914^{[91]}$ and used to obtain zero-point energy corrections, enthalpies and entropies.

Improved energies were obtained by single-point calculations at the B3LYP level, ${ }^{[92,}{ }^{93]}$ with the extended basis set of valence triple zeta quality, labeled def2-TZVPP. ${ }^{[89,}{ }^{94]}$ Energies including the empirical dispersion correction proposed by Grimme for density functional calculations, labeled B3LYP-D ${ }^{[95,}{ }^{96]}$ have also been calculated. In selected cases, RI-MP2 and RI-CC2 energies ${ }^{[97,98]}$ with the same def2-TZVPP basis and their auxiliary basis sets were also obtained. ${ }^{[94,99]}$ The RI-CC2/def2-TZVPP energies values are used as a reference to evaluate and compare the quality of the RI-MP2, B3LYP and B3LYP-D/def2-TZVPP levels on the systems under study.

Solvation free energy corrections were determined using the conductor-like screening model $(\mathrm{COSMO})^{[100]}$ which is a polarizable continuum solvation model. The COSMO calculations were carried out on the gas-phase MARIJ-BP86/def2-SVP geometries, at the B3LYP/def2TZVPP level, with dielectric constants $\varepsilon$ of 78.4 for water, 46.7 for DMSO and 36.6 for acetonitrile and at $\varepsilon=4$, to represent a protein environment in a buried protein site. The solvation free energy correction was added to the final gas phase energy, computed at the RICC2, RI-MP2, B3LYP or B3LYP-D/def2-TZVPP level, and the gas phase thermodynamic corrections were computed at the MARIJ-BP86/def2-SVP level, to give RI-CC2, RI-MP2, B3LYP or B3LYP-D solvation- free energies.

The metal-ligand binding energy $E_{0}$ (or heterolytic bond dissociation energy) was calculated as the interaction energy between the ligand $\mathrm{L}$ and the metal fragment $\mathrm{ML}_{\mathrm{n}}$ as indicated in Eq. (1).

$$
\begin{gathered}
\mathrm{L}_{\mathrm{n}} \mathrm{M}-\mathrm{L} \longrightarrow \mathrm{ML}+\mathrm{L} \\
E_{0}=\mathrm{E}(\mathrm{L})+\mathrm{E}\left(\mathrm{ML}_{\mathrm{n}}\right)-\mathrm{E}\left(\mathrm{ML}_{\mathrm{n}+1}\right)
\end{gathered}
$$

Reed and Weinhold's NBO analysis ${ }^{[101-103]}$ of $\mathrm{Zn}(\mathrm{SR})_{4}{ }^{2-}$ complexes was conducted with Gaussian $^{[104]}$ at the BP86 level using the 6-311+G(2d,2p) basis set for H, C, N and S atoms and the Wachters $[15 \mathrm{~s} 11 \mathrm{p} 6 \mathrm{~d} 2 \mathrm{f} / 10 \mathrm{~s} 7 \mathrm{p} 4 \mathrm{~d} 2 \mathrm{f}]$ basis for $\mathrm{Zn}$. This analysis gives natural localized 
molecular orbitals, molecular charge distribution in terms of natural population analysis charges and Wiberg Bond Index (WBI) in the natural atomic orbital basis. ${ }^{[105]}$ The NBO representation of $a b$ initio wave functions in terms of localized Lewis structures provides a quantitative interpretation of MO interactions.

\section{Results and discussion}

The gas phase binding energy $\left(E_{0}\right)$ of a single zinc thiolate bond in a $\mathrm{Zn}(\mathrm{SR})_{4}{ }^{2-}$ complex was evaluated as the first step of our study. This provided insight into the intrinsic nature of $\mathrm{Zn}-\mathrm{S}$ bonds in biomimetic dianionic zinc complexes or zinc-metalloenzyme active sites in the absence of both solvation and the protein environment. In subsequent calculations, the dissociation of a thiolate from $\mathrm{Zn}(\mathrm{SR})_{4}{ }^{2-}$ complexes was explored and analysed. Finally, the effect of solvation upon this process was modelled.

\section{Gas phase zinc-ligand binding energy}

Calculations of gas phase zinc-ligand binding energies for various ligand substituents $\mathrm{R}$ (Scheme 1) were performed to allow their electronic and steric influences to be evaluated. $\mathrm{Zn}(\mathrm{SR})_{3}(\mathrm{Im})^{-}(\mathrm{Im}=$ imidazole or $\mathrm{N}$-methylimidazole $)$ complexes were also included for comparison (Scheme 2). Of the complexes calculated, 1a and 4a provide simplified models for $\mathrm{ZnCys}_{4}$ and $\mathrm{ZnCys}_{3} \mathrm{His}$ protein sites where cysteine and histidine residues are respectively represented by their side chain and imidazole ring only. $\mathbf{1 d}^{[51,52]} \mathbf{2 b}^{[49]}$ and $\mathbf{4} \mathbf{b}^{[49]}$ are well characterised synthetic complexes for which crystallographic data are available.

Gas phase zinc-thiolate and zinc-imidazole binding energies for $\mathrm{Zn}(\mathrm{SR})_{4}{ }^{2-} \mathbf{1 a - f}$ and $\mathrm{Zn}(\mathrm{SR})_{3}(\mathrm{Im})^{-} \mathbf{4 a - b}$ complexes are given in Table 1. 


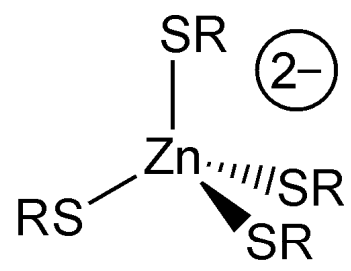

1a-f

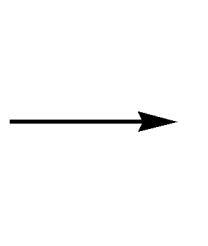

b : $\mathrm{R}=$<smiles>Cc1cc(C)c(C#P)c(C)c1C</smiles>

d :<smiles></smiles>

$\mathbf{a}: \mathrm{R}=\mathrm{CH}_{3}$<smiles></smiles><smiles>[R5][R7]([R5])[Se]</smiles>

2a-f<smiles>[C+][CH+]</smiles>

\section{3a-f}<smiles>C=C=[Ru]c1ccc(N)cc1</smiles><smiles>[R]#Cc1cc(C#N)c(C#N)c(C#N)c1</smiles>

Scheme 1. Dissociation of thiolate ligands from model $\mathrm{Zn}(\mathrm{SR})_{4}{ }^{2-}$ complexes<smiles></smiles>

$4 a$

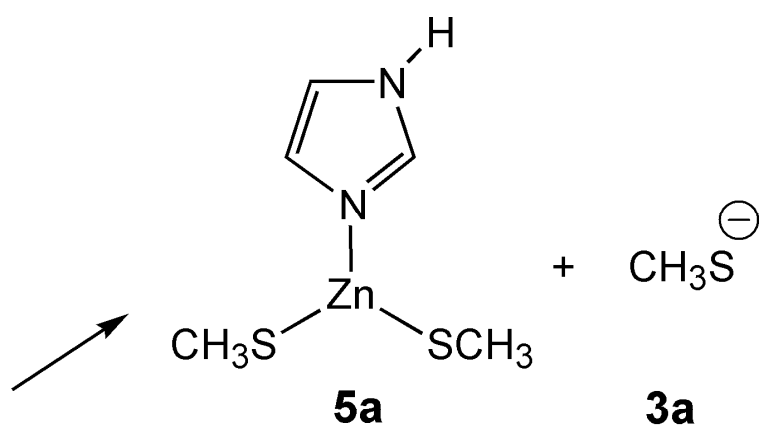<smiles>CC</smiles>

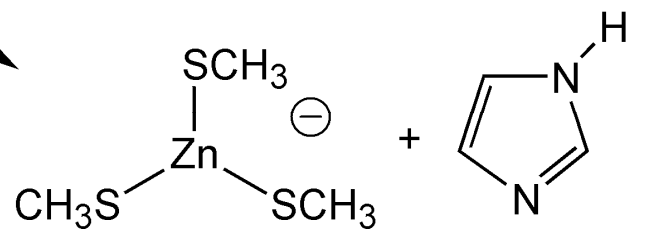<smiles></smiles>

$4 b$

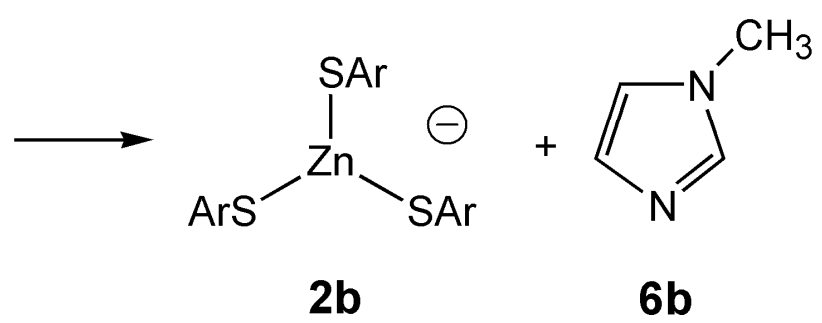<smiles>Cc1cc(C)c(C)c(C)c1C</smiles>

$\mathrm{Me} \mathrm{Me}$

Scheme 2. Dissociation of thiolate and imidazole ligands in $\mathrm{Zn}(\mathrm{SR})_{3}(\mathrm{Im})^{-}$model complexes 
Table 1. Zinc-thiolate and zinc-imidazole binding energies $E_{0}$ (in $\mathrm{kJ} / \mathrm{mol}$ ) for $\mathrm{Zn}(\mathrm{SR})_{4}{ }^{2-}$ and $\mathrm{Zn}(\mathrm{SR})_{3}(\mathrm{Im})^{-}$complexes with def2-TZVPP basis set.

\begin{tabular}{ccccccc}
\hline & B3LYP & B3LYP-D & RI-MP2 & RI-CC2 & ZPE correction & correction to \\
& $E_{0}$ & $E_{0}$ & $E_{0}$ & $E_{0}$ & enthalpies \\
\hline 1a & -185 & -159 & -140 & -140 & -7 & -11 \\
$\mathbf{1 b}$ & -154 & -125 & -108 & -101 & -2 & -4 \\
$\mathbf{1 c}$ & -137 & -115 & & & +1 & -3 \\
$\mathbf{1 d}$ & -127 & -105 & -78 & -74 & +0 & -3 \\
$\mathbf{1 e}$ & -57 & -26 & & & -2 & -5 \\
$\mathbf{1 f}$ & -5 & +29 & & & -2 & -5 \\
$\mathbf{4 a}$ & +154 & +176 & +195 & +197 & -5 & -6 \\
\hline & & & Zn-imidazole bond & -10 \\
\hline $\mathbf{4 a}$ & -15 & +11 & +21 & +23 & -4 & -6 \\
\hline $\mathbf{4 b}$ & +9 & +64 & +88 & +93 & -5 & \\
\hline
\end{tabular}

The zinc-ligand binding energies are highly dependent upon the quality of the calculation. RICC2/def2-TZVPP results were used to provide reference values. These suggest that B3LYP/def2-TZVPP values are underestimated by 38-53 kJ/mol, but RI-MP2/def2-TZVPP provides values that are very similar to the RI-CC2 reference. Including an empirical dispersion correction at the B3LYP level increases the value of $E_{0}$ by about $30 \mathrm{~kJ} / \mathrm{mol}$, thus correcting for slightly more than half of the discrepancy between B3LYP and RI-CC2. This B3LYP-D level may therefore provide an alternative method for estimating absolute binding energies if the system is too big to use the more accurate and expensive post-HF methods. The relative binding energies are satisfactorily reproduced by all methods, so near- RI-CC2 values could be obtained using the more economical B3LYP or B3LYP-D levels. ZPE or enthalpy corrections to the binding energies are small and induce a slight stabilization of the dissociated fragments relative to tetrahedral complexes.

The first major conclusion is that the zinc-thiolate binding energy in $\mathrm{Zn}(\mathrm{SR})_{4}{ }^{2-}$ complexes is negative for all complexes except 1f. Gas phase dissociation of a thiolate ligand from a dianionic $\mathrm{Zn}(\mathrm{SR})_{4}{ }^{2-}$ complex is therefore exothermic for 1a-e so, for unsolvated systems, these complexes are thermodynamically less stable than their separate $\mathrm{RS}^{-}$and $\mathrm{Zn}(\mathrm{SR})_{3}{ }^{-}$ fragments. However, in complex $\mathbf{4 a}$, the thiolate ligand dissociation is endothermic. We also noticed that the zinc-imidazole binding energy is positive in complexes $\mathbf{4 a}$ and $\mathbf{4 b}$. This 
difference between $\mathrm{Zn}(\mathrm{SR})_{4}{ }^{2-}$ and $\mathrm{Zn}(\mathrm{SR})_{3}(\mathrm{Im})^{-}$complexes with respect to dissociation reflects their global charges. Loss of a thiolate ligand from the dianionic complex to produce two monoanions, which dramatically lowers Coulomb repulsion, is a more favourable process than any dissociation from the singly- charged $\mathrm{Zn}(\mathrm{SR})_{3}(\mathrm{Im})^{-}$.

The overall energy for a single $\mathrm{Zn}-\mathrm{S}$ bond, $E_{0}$ can be divided into three physically meaningful components. These are $i)$ the deformation energy $\left(E_{d e f}\right)$ necessary to release the fragments from their geometry and electronic state in the complex to their equilibrium geometry and electronic state as free entities, $i i)$ the orbital $\left(E_{\text {orb }}\right)$ and $\left.i i i\right)$ the electrostatic $\left(E_{\text {elec }}\right)$ interaction energies. Previous studies indicate that $E_{d e f}$ is close to zero and that $E_{\text {orb }}$ and $E_{\text {elec }}$ have positive and broadly similar values in the neutral complex $\mathrm{ZnL}\left(\mathrm{SC}_{6} \mathrm{~F}_{5}\right)$, so the $\mathrm{Zn}-\mathrm{S}$ binding energy is high $(550 \mathrm{~kJ} / \mathrm{mol}) .{ }^{[42]} \mathrm{In} \mathrm{Zn}(\mathrm{SR})_{4}{ }^{2-}$ complexes, the electrostatic interaction between $\mathrm{RS}^{-}$and $\mathrm{Zn}(\mathrm{SR})_{3}{ }^{-}$probably becomes strongly repulsive, so that the negative $E_{\text {elec }}$ term offsets the attractive orbital interaction given by $E_{o r b}$ (vide infra). Monoanionic complexes obviously lie between neutral and dianionic complexes.

Changing the nature of the thiolate substituents confirms the importance of Coulomb repulsions. Replacing the methylthiolates in 1a with the phenylthiolates in 1d allows negative charge to be delocalised, and this increases the zinc-thiolate binding energy by $58 \mathrm{~kJ} / \mathrm{mol}$. The importance of the electron-withdrawing nature of the thiolate substituents was confirmed in further calculations which show that $E_{0}$ increases from $-137 \mathrm{~kJ} / \mathrm{mol}$ for $p$-aminophenylthiolate (1c) to $-5 \mathrm{~kJ} / \mathrm{mol}$ for $m, p, m$ '-tricyano-phenylthiolate (1f) because of diminishing Coulomb repulsion between the $\mathrm{RS}^{-}$and $\mathrm{Zn}(\mathrm{SR})_{3}{ }^{-}$fragments as the negative charge is transferred onto the substituents.

Figure 1 shows that the value of $E_{0}$ is reflected in the zinc-sulfur bond length and a good linear correlation is observed between $\mathrm{Zn}-\mathrm{S}$ bond lengths and binding energies. This contrasts with the case of metal-thiolate bonds in a $\left[\mathrm{M}^{\mathrm{II}}(\right.$ pyrazolyl $\left.)\left(\mathrm{SC}_{6} \mathrm{~F}_{5}\right)\right]$ series where the metalthiolate bond length reflects the electronic configuration of the metal ion. ${ }^{[42]}$ As might be expected, the largest deviation observed in figure 1 is found for the sterically hindered $\mathbf{1 b}$ (vide infra); if $\mathbf{1 b}$ is excluded, so as to give a series of complexes wherein steric effects are negligible, a correlation coefficient of 0.9967 is found. 


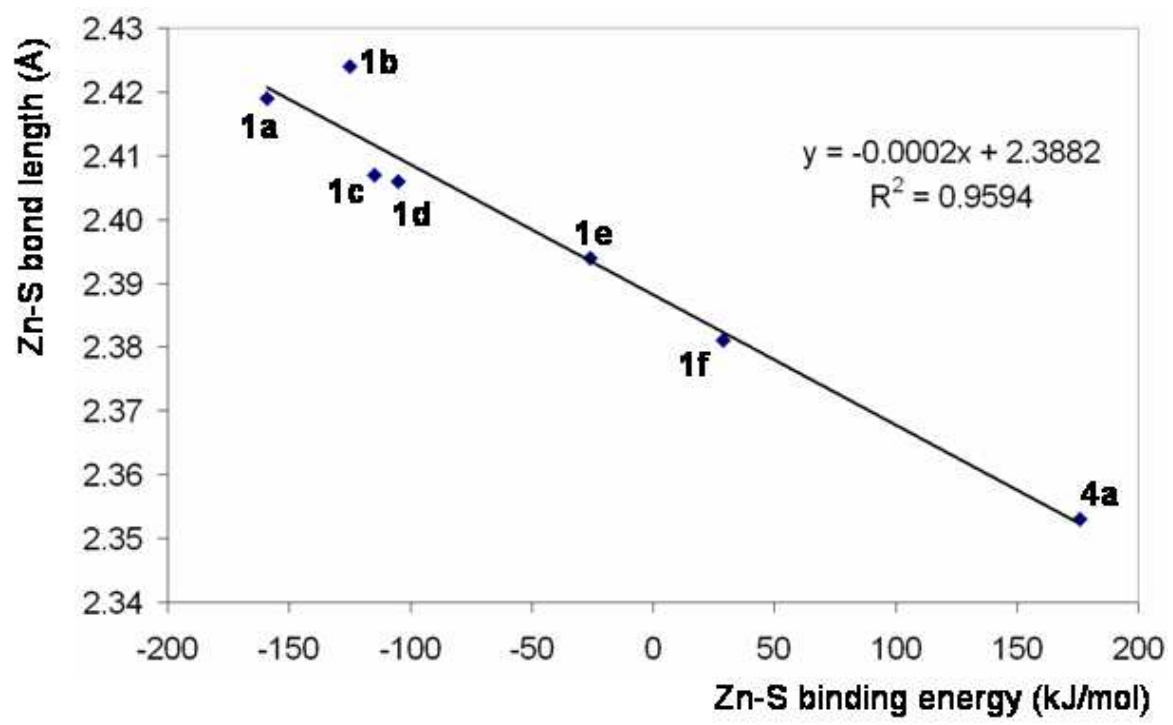

Figure 1. Plot of calculated B3LYP-D Zn-S binding energy versus Zn-S bond length for complexes 1a-f and 4a.

Given the large number of proteins possessing a $\left[\mathrm{Zn}(\mathrm{Cys})_{4}\right]^{2-}$ sites, it is surprising to find such thermodynamic metastability within their cores. This suggests $(i)$ the existence of an energy barrier for the dissociation of thiolate ligands from $\mathrm{Zn}(\mathrm{SR})_{4}{ }^{2-}$ complexes and (ii) that environmental effects may play an important role in stabilising such species.

\section{The zinc-thiolate dissociation process}

Figure 2 depicts the dissociation of $\mathrm{Zn}\left(\mathrm{SC}_{6} \mathrm{H}_{5}\right)_{4}{ }^{2-} \mathbf{1 d}$ as a potential energy profile and shows how $\mathbf{1 d}$ is linked to its component fragments $\mathrm{Zn}\left(\mathrm{SC}_{6} \mathrm{H}_{5}\right)_{3}{ }^{-} \mathbf{2 d}$ and $\mathrm{SC}_{6} \mathrm{H}_{5}{ }^{-} \mathbf{3 d}$ through the transition state TS1-2d. The energy barrier to dissociation of $\mathbf{1 d}\left(E_{\text {diss }}\right)$ is $81 \mathrm{~kJ} / \mathrm{mol}$ at the RICC2/def2-TZVPP level and the barrier to formation of $1 \mathbf{d}$ from its separated fragments $\left(E_{\text {form }}\right)$ is $155 \mathrm{~kJ} / \mathrm{mol}$. The rather low value for $E_{\text {diss }}$ is comparable with the internal energy of $\mathbf{1 d}$ at $298 \mathrm{~K}$, and this indicates that $\mathbf{1 d}$ should dissociate in the gas phase at room temperature. This is in reassuring agreement with mass spectrometry experiments wherein only $\mathbf{2 d}$ is observed. ${ }^{[106]}$ Conversely, the association reaction to form the fourth zinc-sulfur bond is highly endothermic and also has a significant activation energy. 


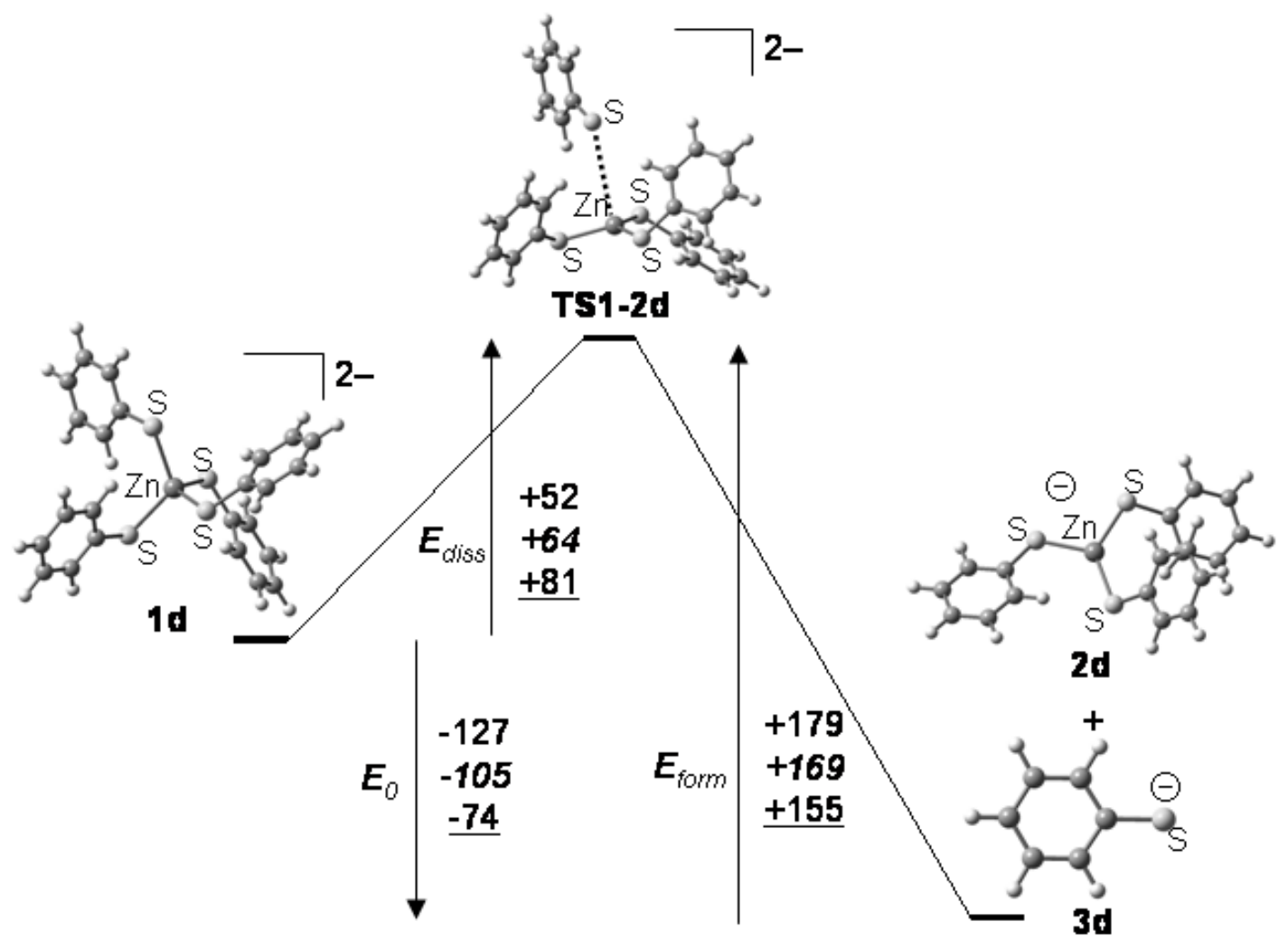

Figure 2. The energy profile for the dissociation of the zinc-thiolate bond pathway in complex 1d. Energy values are given in $\mathrm{kJ} / \mathrm{mol}$ for the B3LYP/def2-TZVPP (standard text), B3LYP-D/def2-TZVPP (italic) and RI-CC2/def2-TZVPP (underlined) levels. All values were obtained using geometries calculated at the MARIJ-BP86/def2-SVP level.

Increasing the quality of the calculation stabilises 1 d by $53 \mathrm{~kJ} / \mathrm{mol}$ and TS1-2d by $24 \mathrm{~kJ} / \mathrm{mol}$ relative to the separated fragments $\mathbf{2 d}$ and $\mathbf{3 d}$, with the result that $E_{\text {form }}$ falls and $E_{\text {diss }}$ rises when B3LYP-D and RI-CC2 levels are used instead of B3LYP. Similar computational trends are observed for each of the $\mathrm{Zn}(\mathrm{SR})_{4}{ }^{2-}$ complexes (Table 2). Thus, whilst B3LYP gives absolute values which are globally inaccurate, both B3LYP and B3LYP-D give acceptable relative values.

As is shown in Table 2, a transition state along the $\mathrm{Zn}$-thiolate dissociation pathway could be located for all $\mathrm{Zn}(\mathrm{SR})_{4}{ }^{2-}$ complexes. Thus, even when the $\mathrm{Zn}(\mathrm{SR})_{4}{ }^{2-}$ complex is more stable than its separated fragments, as in 1f, the bond dissociation pathway goes through a transition state. 
Table 2. Energy barriers for the dissociation of tetrahedral $\mathrm{Zn}(\mathrm{SR})_{4}{ }^{2-}$ complexes $\left(E_{\text {diss }}\right)$ and for zinc-thiolate bonding from separated fragments $\left(E_{\text {form }}\right)$. Results obtained using the def2TZVPP basis set, expressed in $\mathrm{kJ} / \mathrm{mol}$.

\begin{tabular}{|c|c|c|c|c|c|c|}
\hline & B3LYP & B3LYP-D & B3LYP & B3LYP-D & \multicolumn{2}{|c|}{$\mathrm{Zn}-\mathrm{S}$ distance } \\
\hline & \multicolumn{2}{|c|}{$E_{\text {diss }}$} & \multicolumn{2}{|c|}{$E_{\text {form }}$} & $\mathbf{1}^{\mathrm{a}}$ & TS1-2 $^{\mathrm{b}}$ \\
\hline $1 \mathbf{a}$ & $+39^{c}$ & +51 & $+224^{\mathrm{d}}$ & +210 & 2.419 & 4.110 \\
\hline $1 b$ & +37 & +37 & +191 & +162 & 2.424 & 3.831 \\
\hline 1c & +41 & +53 & +179 & +167 & 2.407 & 4.239 \\
\hline 1d & $+52^{\mathrm{e}}$ & +64 & $+179^{\mathrm{f}}$ & +169 & 2.406 & 4.381 \\
\hline $1 \mathrm{e}$ & +71 & +88 & +128 & +115 & 2.394 & 5.084 \\
\hline 1f & +94 & +113 & +99 & +84 & 2.381 & 5.193 \\
\hline
\end{tabular}

${ }^{\mathrm{a}} \mathrm{Zn}-\mathrm{S}$ bond length (in $\AA$ ) in the $\mathrm{Zn}(\mathrm{SR})_{4}{ }^{2-}$ complexes labeled $1 .{ }^{\mathrm{b}} \mathrm{Zn} \cdot \mathrm{S}$ distance (in $\AA$ ) in the transition state labeled TS1-2. ${ }^{\mathrm{c}}+70$ and $+71 \mathrm{~kJ} / \mathrm{mol}$ at the RI-MP2 and RI-CC2 levels respectively. ${ }^{\mathrm{d}}+210$ and $+211 \mathrm{~kJ} / \mathrm{mol}$ at the RI-MP2 and RI-CC2 levels respectively. ${ }^{\mathrm{e}}+78$ and $+81 \mathrm{~kJ} / \mathrm{mol}$ at the RI-MP2 and RI-CC2 levels respectively. ${ }^{\mathrm{f}}+156$ and $+155 \mathrm{~kJ} / \mathrm{mol}$ at the RI-MP2 and RI-CC2 levels respectively.

Potential energy surfaces such as those as described in Figure 2 and Table 2 are unusual in coordination chemistry and reveal the peculiarity of these systems. Dissociation of a ligand from a transition metal complex is normally expected to be a barrierless endothermic process but the unusual surfaces observed here nicely explain the apparent contradiction between the high stability of $\mathrm{ZnCys}_{4}$ sites and the kinetic lability of the $\mathrm{Zn}-\mathrm{S}$ bond (vide infra). They also provide a fundamental insight in the nature of the $\mathrm{Zn}-\mathrm{S}$ bond.

Metal-ligand bond strength is usually equal to the bond dissociation energy $E_{0}{ }^{[107]}$ This is not the case for the complexes studied here, where the $\mathrm{Zn}-\mathrm{S}$ bond strength is estimated as $E_{d i s s}$, the energy necessary to break the bond. This energy is low when compared with the several hundreds of $\mathrm{kJ} / \mathrm{mol}$ that typify most metal-ligand single bonds. Interestingly, as with $E_{0}$, the $\mathrm{Zn}-\mathrm{S}$ bond strength in $\mathrm{Zn}(\mathrm{SR})_{4}{ }^{2-}$ complexes reflects the electron-withdrawing nature of substituent R so that $E_{\text {diss }}$ correlates with the $\mathrm{Zn}-\mathrm{S}$ bond length (Table 2). Once again, as the substituent becomes more electron-withdrawing, the $\mathrm{Zn}-\mathrm{S}$ bond length in $\mathbf{1}$ shortens and the $E_{\text {diss }}$ value rises.

Whilst Coulomb repulsion between the anionic $\mathrm{RS}^{-}$and $\mathrm{Zn}(\mathrm{SR})_{3}{ }^{-}$fragments provides a reasonable explanation of this trend, it does not, in itself, justify the large energy barrier to bond dissociation. However, the TS1-2 transition state $\mathrm{Zn} \cdots \mathrm{S}$ distances reported in Table 2 shed light upon the dissociation, with the lengthening of the $\mathrm{Zn} \cdots \mathrm{S}$ distances, occurring upon 
passing from 1 to TS1-2, by between $60 \%$ and $120 \%$ clearly indicating a late transition state. Transition states showing large interfragment separations of this sort are typically observed during the ionic fragmentation of doubly charged cations ${ }^{[108]}$ and this suggests that the avoided-crossing model used to describe the process of dication fragmentation into monocations ${ }^{[109]}$ may also adequately describe the dianionic dissociation of $\mathrm{Zn}(\mathrm{SR})_{4}{ }^{2-}$ complexes into $\mathrm{RS}^{-}$and $\mathrm{Zn}(\mathrm{SR})_{3}{ }^{-}$fragments.

The avoided-crossing model rationalises the dissociation of metastable dication $\mathrm{AB}^{2+}$ into monocation $\mathrm{A}^{+}$and $\mathrm{B}^{+}$fragments in terms of an avoided crossing between a purely repulsive covalent structure energy curve (diabatic curve correlating with $\mathrm{A}^{+}+\mathrm{B}^{+}$) and an attractive ionic curve (diabatic curve correlating with $\mathrm{A}^{2+}$ and $\mathrm{B}$ ). To investigate how such diabatic curves might apply to the dissociation of $\mathrm{Zn}(\mathrm{SR})_{4}{ }^{2-}$, we performed an $\mathrm{NBO}$ analysis of $\mathrm{Zn}(\mathrm{SR})_{4}{ }^{2-}$ complexes 1a-f (Table 3).

Table 3. NBO analysis of $\mathrm{Zn}(\mathrm{SR})_{4}{ }^{2-}$ complexes 1a-f.

\begin{tabular}{cccc}
\hline & $\mathrm{WBI}^{\mathrm{a}}$ & $\mathrm{q}(\mathrm{Zn})^{\mathrm{b}}$ & $\mathrm{q}(\mathrm{SR})^{\mathrm{b}}$ \\
\hline 1a & 0.268 & 1.251 & -0.813 \\
$\mathbf{1 b}$ & 0.254 & 1.292 & -0.823 \\
$\mathbf{1 c}$ & 0.269 & 1.245 & -0.811 \\
$\mathbf{1 d}$ & 0.270 & 1.240 & -0.810 \\
1e & 0.273 & 1.228 & -0.807 \\
1f & 0.273 & 1.226 & -0.807
\end{tabular}

${ }^{\mathrm{a}} \mathrm{Zn}-\mathrm{S}$ Wiberg Bond Index. ${ }^{\mathrm{b}}$ electronic charge of $\mathrm{Zn}$ atom and SR groups.

A charge analysis of the metal atom and its ligands indicates a net charge transfer from each thiolate group to the metal of approximately $20 \%$ of its negative charge (ca. 0.19 electrons). The Wiberg Bond Index, a measure for covalent bonding, ${ }^{[105]}$ shows that the $\mathrm{Zn}-\mathrm{S}$ bond order is close to 0.27 in all cases, and these near- invariant WBI values reveal that the electronic nature of the $\mathrm{Zn}-\mathrm{S}$ bond does not vary significantly as a function of the thiolate group except in the case of $\mathbf{1 b}$, the complex having ortho,ortho'-methyl substituents on the phenylthiolate. Complex $\mathbf{1 b}$ is unlike $\mathbf{1 d}$ and $\mathbf{2 b}$ in that it has never been observed in solution. Its nonformation has been attributed to intraligand steric repulsions ${ }^{[49]}$ and our results reveal how the hindrance about the thiolate ligands affects the electronic structure of $\mathbf{1 b}$. The sterically imposed lengthening of the $\mathrm{Zn}-\mathrm{S}$ bond length in $\mathbf{1 b}$ relative to $\mathbf{1 c}$ and $\mathbf{1 d}$ (2.424 vs. 2.407 and 
$2.406 \AA$ ) induces weaker Zn-S covalent bonding (WBI of 0.254 vs. 0.269 and 0.270 ) and is consistent with the lower calculated $\mathrm{S}$ to $\mathrm{Zn}$ charge transfer $(0.177$ vs. 0.189 and 0.190 electrons).

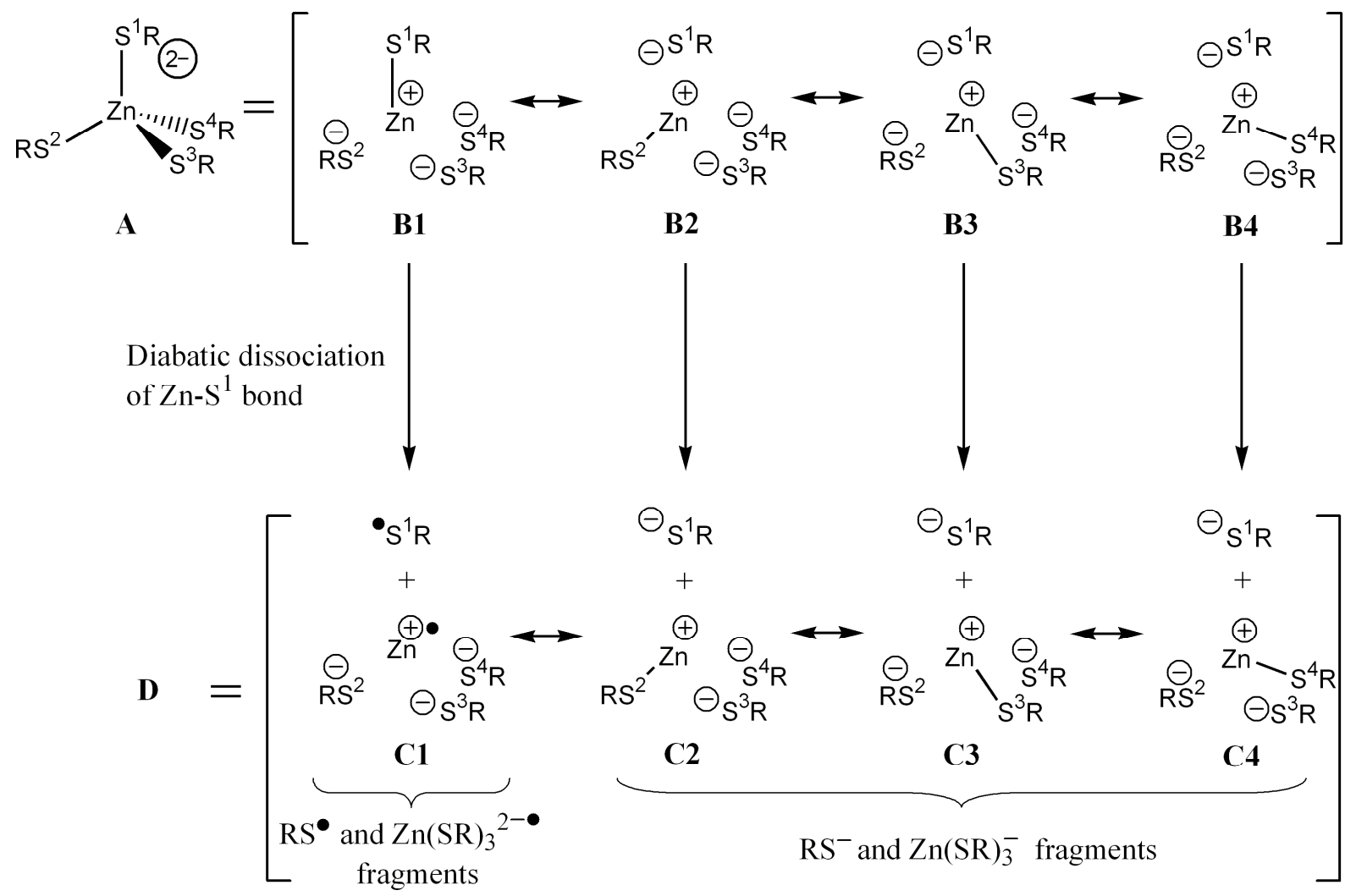

Scheme 3. Qualitative description of the bonding in $\mathrm{Zn}(\mathrm{SR})_{4}{ }^{2-}$ complexes (top) and of the resulting fragments after diabatic disruption of one $\mathrm{Zn}-\mathrm{S}$ bond (bottom).

The values in Table 3 allow a qualitative description of the metal-ligand bonding in $\mathrm{Zn}(\mathrm{SR})_{4}{ }^{2-}$ complexes to be formulated (Scheme 3 ). The $\mathrm{Zn}-\mathrm{S}$ bond has only a small degree of covalency and pronounced ionic character. The simplest and most commonly used description, a single Lewis structure having four covalent $\sigma \mathrm{S}-\mathrm{Zn}$ bonds and referred to as $\mathbf{A}$ in Scheme 3, therefore does not give an acceptable representation of the electronic environment around the zinc; a far better depiction of the computed electronic density is provided by the four resonance structures B1-4. Here, the central metal cation forms one covalent and three ionic bonds to its four ligands, a bonding description that is consistent with earlier studies of the active site of the alcohol dehydrogenase $\mathrm{Zn}$ (II)-metalloenzyme deduced through topological analysis of the Electron Localization Function (ELF) and a Reduced Variational Space (RVS) energy decomposition analysis. ${ }^{[110,111]}$ Both the ELF and RVS studies show that the Zn-S 
bond is predominantly electrostatic and that the valence shell electrons (lone pairs) of the $\mathrm{S}^{-}$ cysteinate are poorly localized towards the zinc and weakly shared with it.

This electronic description based on four equivalent resonance structures implies that the diabatic disruption of one specific $\mathrm{Zn}-\mathrm{S}$ bond gives $\mathbf{D}$ which is the result of $75 \%$ heterolytic cleavage (to the $\mathrm{RS}^{-}$and $\mathrm{Zn}(\mathrm{SR})_{3}{ }^{-}$fragments arising from structures $\mathbf{C 2 - 4}$ ) and $25 \%$ homolytic cleavage (to the $\mathrm{RS}^{\bullet}$ and $\mathrm{Zn}(\mathrm{SR})_{3}{ }^{2-\bullet}$ fragments arising from structure C1) (Scheme $3)$.

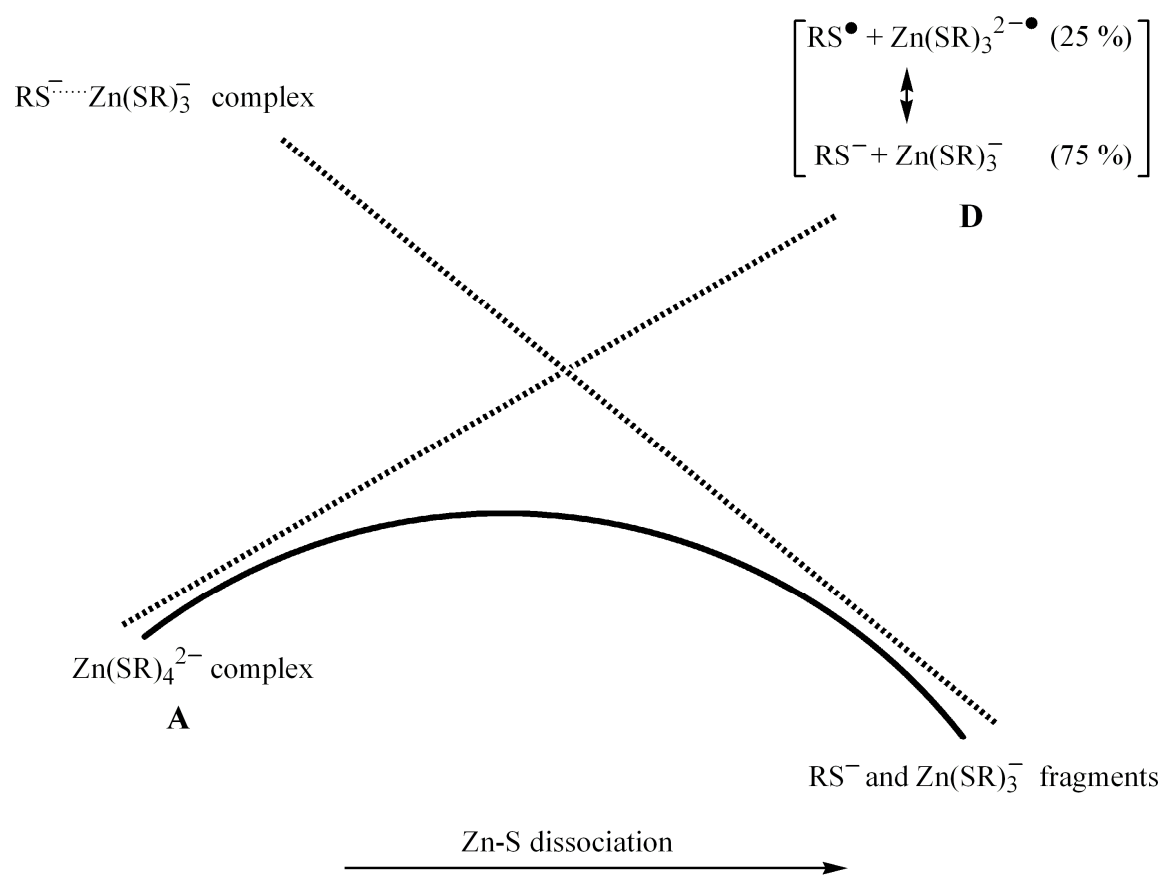

Scheme 4. Avoided-crossing model for dissociation of $\mathrm{Zn}(\mathrm{SR})_{4}{ }^{2-}$ into $\mathrm{RS}^{-}$and $\mathrm{Zn}(\mathrm{SR})_{3}{ }^{-}$.

In scheme 4, the potential energy curve from $\mathrm{Zn}(\mathrm{SR})_{4}{ }^{2-}$ to its $\mathrm{RS}^{-}$and $\mathrm{Zn}(\mathrm{SR})_{3}{ }^{-}$fragments is shown. This curve is considered as arising from an avoided crossing between an attractive and a repulsive diabatic curves. The repulsive energy during $\mathrm{Zn}-\mathrm{S}$ bond formation is represented by the diabatic curve, correlating with $\mathrm{RS}^{-}+\mathrm{Zn}(\mathrm{SR})_{3}{ }^{-}$, which leads to a hypothetical complex wherein no charge is transferred from the incoming thiolate group to the metal. This complex is depicted as $\mathrm{RS}^{-\cdots} \mathrm{Zn}(\mathrm{SR})_{3}{ }^{-}$. Along the attractive diabatic curve, the $\mathrm{Zn}(\mathrm{SR})_{4}{ }^{2-}$ complex correlates with the fictitious products $\mathbf{D}$, which reflect the characteristics of the resonance hybrids C1-4, 
This analysis indicates that the existence of a transition state during $\mathrm{Zn}-\mathrm{S}$ bond dissociation results from thiolate-to-metal charge transfer in the $\mathrm{Zn}(\mathrm{SR})_{4}{ }^{2-}$ complex, because any dissociation along a diabatic curve would partially give rise to the high energy fragments $\mathrm{RS}^{\bullet}$ and $\mathrm{Zn}(\mathrm{SR})_{3}{ }^{2-\bullet}$ that contribute to product $\mathbf{D}$. Calculation of the energy difference between $\mathrm{Zn}(\mathrm{SR})_{4}{ }^{2-}$ complex and its diabatic dissociated product $\mathbf{D}$ confirms the endothermicity of this process (Figure 3). Furthermore, the activation barrier to dissociation rises as the diabatic dissociation of $\mathrm{Zn}(\mathrm{SR})_{4}{ }^{2-}$ becomes more endothermic (Figure 3), as would be expected when the C1-4 resonance structures resulting from thiolate-to-metal charge-transfer in the $\mathrm{Zn}(\mathrm{SR})_{4}{ }^{2-}$ complex are correlated to the transition state found on the $\mathrm{Zn}-\mathrm{S}$ bond dissociation trajectory.

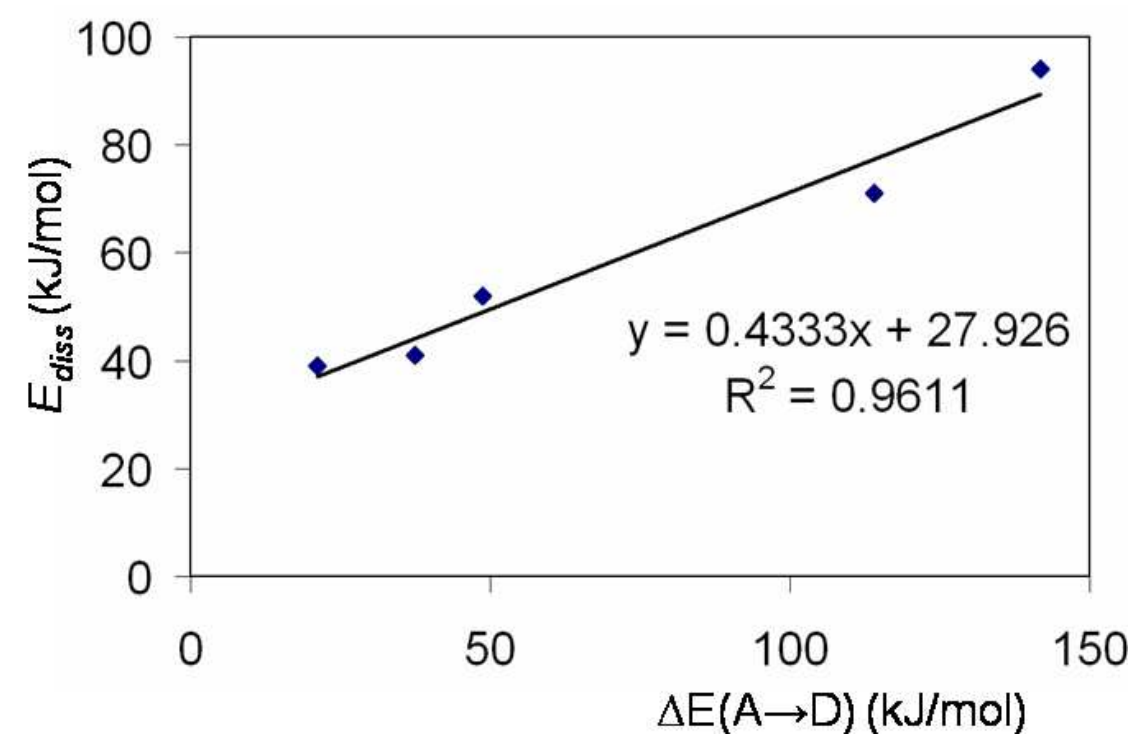

Figure 3. Plot of the energy difference $\Delta \mathrm{E}(\mathrm{A} \rightarrow \mathrm{D})$ along the diabatic dissociation process from complex $\mathbf{A}$ to products $\mathbf{D}$ versus dissociation energy $E_{\text {diss }}$.

\section{Solvation effect}

All of the above results have been obtained from gas phase calculations. They imply that the dianionic $\mathrm{Zn}(\mathrm{SR})_{4}{ }^{2-}$ complexes are energetically metastable (1a-e) or weakly stable (1f) toward $\mathrm{Zn}-\mathrm{S}$ bond dissociation and that, on the contrary, the monoanionic $\mathrm{Zn}(\operatorname{Im})(\mathrm{SR})_{3}{ }^{-}$class is stable toward both $\mathrm{Zn}-\mathrm{S}$ and $\mathrm{Zn}-\mathrm{N}$ bond dissociation in the gas phase. Such results are at variance with much experimental data derived from solution measurements, are clearly false 
for complex 1d whose X-ray structure has been determined, ${ }^{[51,52]}$ and cannot explain the stability of $\mathrm{ZnCys}_{4}$ fingers. To resolve these apparent contradictions, we carried out final energy calculations including solvation effects. The results are summarized in Table 4.

Table 4. Zinc-thiolate and zinc-imidazole binding free energies in the gas phase $\left(G_{0}\right)$ and in water $\left(G_{0}^{78.4}\right)$, and solvation free energies barriers $\left(G^{78.4}\right.$ diss $)$ (in $\mathrm{kJ} / \mathrm{mol}$ ) for $\mathrm{Zn}(\mathrm{SR})_{4}{ }^{2-}$ and $\mathrm{Zn}(\mathrm{SR})_{3}(\mathrm{Im})^{-}$complexes with def2-TZVPP basis set.

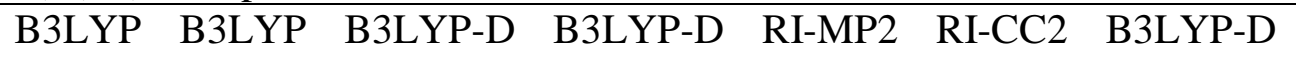

$$
G_{0} \quad G_{0}^{78.4} \quad G_{0} \quad G_{0}^{78.4} \quad G_{0}^{78.4} \quad G_{0}^{78.4} \quad G^{78.4} \text { diss }
$$

\begin{tabular}{|c|c|c|c|c|c|c|c|}
\hline \multicolumn{8}{|c|}{ Zn-thiolate bond } \\
\hline $1 \mathbf{a}$ & -237 & -52 & -211 & -26 & -7 & $-7^{\mathrm{a}}$ & $+51^{\mathrm{b}}$ \\
\hline $1 b$ & -217 & -81 & -188 & -51 & -34 & $-27^{\mathrm{c}}$ & +34 \\
\hline 1c & -182 & -18 & -160 & +5 & & & +61 \\
\hline $1 d$ & -174 & -11 & -152 & +12 & +39 & $+43^{\mathrm{d}}$ & $+67^{\mathrm{e}}$ \\
\hline 1e & -108 & -3 & -78 & +28 & & & +75 \\
\hline $\mathbf{1 f}$ & -57 & +3 & -23 & +37 & & & +87 \\
\hline $4 \mathbf{a}$ & +103 & -3 & +125 & +19 & +38 & +40 & \\
\hline \multicolumn{8}{|c|}{ Zn-imidazole bond } \\
\hline $4 \mathbf{a}$ & -63 & -59 & -37 & -33 & -23 & -21 & \\
\hline $4 b$ & -49 & -61 & +5 & -7 & +17 & $+22^{\mathrm{f}}$ & \\
\hline
\end{tabular}

${ }^{\mathrm{a}}$ values of $-63,-11$ and $-9 \mathrm{~kJ} / \mathrm{mol}$ in buried site, acetonitrile and DMSO respectively. ${ }^{\mathrm{b}}+71$ $\mathrm{kJ} / \mathrm{mol}$ at the RI-CC2 level. ${ }^{\mathrm{c}}$ value of $-30 \mathrm{~kJ} / \mathrm{mol}$ in acetonitrile. ${ }^{\mathrm{d}}$ value of $+41 \mathrm{~kJ} / \mathrm{mol}$ in DMSO. ${ }^{\mathrm{e}}+84 \mathrm{~kJ} / \mathrm{mol}$ at the RI-CC2 level. ${ }^{\mathrm{f}}$ value of $+22 \mathrm{~kJ} / \mathrm{mol}$ in acetonitrile.

As expected, compared to gas phase binding energies $E_{0}$ (Table 1), gas phase binding free energies $G_{0}$ are decreased by ca. $50 \mathrm{~kJ} / \mathrm{mol}$ due to the dissociation of one metal-ligand bond. Inclusion of water solvation effect stabilises the complexes 1a-f with respect to the fragments resulting from $\mathrm{Zn}-\mathrm{S}$ bond dissociation.

The trends reflect the overall electronic charge of the complex, the degree to which charge is delocalised into the ligands, and the way the solvation free energy corrections vary with the size of the molecule. Small monoanions like 3a are better stabilized by solvation than larger monoanions such as $\mathbf{4 a}$ and, naturally, anions are much more stabilized than neutrals. As a consequence, solvation has only a marginal effect upon $\mathrm{Zn}-\mathrm{N}$ dissociation in $\mathbf{4 a}$ and $\mathbf{4 b}$. The solvation of dianions such as 1a provides greater stabilisation than sum of the solvation of the component monoanions (e.g. 2a or 3a), and charge-delocalized dianions (e.g. 1f) are less 
stabilized by solvation than those having more localized charges (e.g. 1a). Overall, the stabilising effect of solvation means that dissociation free energies along the series from 1a-f vary far more in the gas phase (from -211 to $-23 \mathrm{~kJ} / \mathrm{mol}$ ) than they do in solution (from -51 to $+37 \mathrm{~kJ} / \mathrm{mol}$ in water at the B3LYP-D level).

We have already noted that, B3LYP, B3LYP-D, RI-MP2 and RI-CC2 calculations give the same trends but different absolute values. At the B3LYP level with inclusion of a solvation model, all tetrahedral complexes except 1 f are metastable toward both $\mathrm{Zn}-\mathrm{S}$ and $\mathrm{Zn}-\mathrm{N}$ bond dissociation, which is in contradiction with experimental results. At the improved B3LYP-D level, a better agreement between the calculated and experimental data appears because of a stabilisation of complexes 1c-e and $4 \mathbf{a}$ with respect to $\mathrm{Zn}-\mathrm{S}$ bond dissociation in water. However, even at this level, we compute erroneously that $\mathbf{4 b}$ should not be stable because of a slightly exothermic Zn-N bond dissociation. Remarkably, our most accurate RI-CC2 calculations, as well as RI-MP2 calculations, give complete coherence with the experimental results: $\mathbf{1 b}$ is metastable toward $\mathrm{Zn}-\mathrm{S}$ bond dissociation and only $\mathbf{2} \mathbf{b}$ can thus be obtained in acetonitrile; ${ }^{[49]} \mathbf{1 d}$ is thermodynamically stable and can be synthetized and crystallized in DMSO; ${ }^{[51,52]} \mathbf{4 b}$ is stable toward $\mathrm{Zn}-\mathrm{N}$ dissociation, as is illustrated by its synthesis from $\mathbf{2 b}$ in acetonitrile. ${ }^{[49]}$

Our data predict that complexes $1 \mathbf{a}$ and $4 \mathbf{a}$ are metastable with respect to $\mathrm{Zn}-\mathrm{S}$ and $\mathrm{Zn}-\mathrm{N}$ bond dissociations respectively, which seems reasonable given that they have not been reported experimentally. Indeed, despite the considerable effort devoted to the synthesis of chemical models for the active and structural sites of zinc metalloproteins, neither $\mathrm{Zn}(\mathrm{SR})_{4}{ }^{2-}$ nor $\mathrm{Zn}(\mathrm{Im})(\mathrm{SR})_{3}{ }^{-}$species seem to have been prepared in cases where $\mathrm{R}$ is a simple alkyl group; these complexes appear only to exist if the alkyl- substituted ligand is bidentate. ${ }^{[55]}$ Such observations contrast starkly with the huge number of natural $\mathrm{ZnCys}_{4}$ and $\mathrm{ZnHisCys}_{3}$ cores which are observed in proteins. At the present time, we can propose three hypotheses to explain this apparent paradox : (i) the first, already advanced by several authors, ${ }^{[112-114]}$ is that not all of the cysteine ligands in $\mathrm{ZnCys}_{4}$ and $\mathrm{ZnHisCys}_{3}$ cores in proteins are deprotonated; this would diminish the Coulomb repulsion between the zinc ligands. (ii) The peptide chains which support $\mathrm{ZnCys}_{4}$ and $\mathrm{ZnHisCys}_{3}$ cores are often short, which should reduce the entropic drive for $\mathrm{Zn}-\mathrm{S}$ or $\mathrm{Zn}-\mathrm{N}$ bond dissociation. Given that the negative values of the metal-ligand binding free energies in 1a or $\mathbf{4 a}$ are small, this may be enough to invert the stability of four $v s$. three coordinate complexes ( $c f$ bidentate alkyl thiolate ligands). ${ }^{[55]}$ (iii) $\mathrm{ZnCys}_{4}$ and 
$\mathrm{ZnHisCys}_{3}$ cores are surrounded by water and/or other protein components which make hydrogen bonds to the cysteine sulfur and/or the histidine $\mathrm{NH}$ group. Such a local environment would be poorly reproduced by a continuum solvation model, and might lead to large modifications in the properties of the zinc site. ${ }^{[15]}$ Cationic residues such as alkylammonium lysine side chains are, indeed, often found in the second coordination shell of zinc finger cores, and these could modify the electronic distribution around the metal in a way that diminishes the Coulomb repulsion between the directly bound ligands. It is also quite possible that different explanations apply to different sites. Dissociation of one $\mathrm{Zn}-\mathrm{S}$ bond from a classical $\mathrm{ZnCys}_{4}$ core located in a buried protein site is computed to be highly exothermic $(63 \mathrm{~kJ} / \mathrm{mol})$, but the entropic benefits normally associated with $\mathrm{Zn}-\mathrm{S}$ bond dissociation (for example $41 \mathrm{~kJ} / \mathrm{mol}$ for 1a) will become essentially negligible if the site is surrounded by a full hydrogen bond network. Conversely, a cysteine arm might dissociate more easily from a $\mathrm{ZnCys}_{4}$ core located at a protein / water interface where it would be less constrained by a rigid hydrogen bond network. However in such cases, Zn-S bond dissociation would only be slightly exothermic $(7 \mathrm{~kJ} / \mathrm{mol})$. Further work is therefore clearly needed to establish which of the above hypotheses affect the stability of $\mathrm{ZnCys}_{4}$ and $\mathrm{ZnHisCys}_{3}$ cores in proteins, and when.

Our results shed new light on the kinetic lability of $\mathrm{ZnCys}_{4}$ cores. It should be noted that for 1a, which is frequently used as a model for the interaction of zinc with its inner shell ligand system in proteins, the $\mathrm{Zn}-\mathrm{S}$ binding free energy in water is very small. It is thus conceivable that minor modifications in the environment around 1a will dictate the formation or disruption of one $\mathrm{Zn}-\mathrm{S}$ bond. $\mathrm{Cys}_{4}$ and $\mathrm{HisCys}_{3}$ cores bind zinc very tightly, but the fourth ligand in $(\mathrm{MeS})_{3} \mathrm{Zn}-\mathrm{L}^{-}\left(\mathrm{L}=\mathrm{Im}\right.$ or SMe$\left.{ }^{-}\right)$complexes is only weakly bound. This means that the strong Lewis acidity of $\mathrm{Zn}^{2+}$ is noticeably reduced after coordination of three thiolate ligands, so that the fourth ligand cannot be coordinated in the absence of favourable environmental effects. As a consequence, such cores have strong coordination to zinc but high kinetic lability of one of the zinc ligands. It is also noteworthy that formation of polynuclear zinc systems from bior tricoordinated zinc fragments could allow greater thermodynamic stability and be an alternative to coordination of a fourth ligand. Whatever the case, and even if this fluctuating coordination to zinc is slowed by a free energy barrier (Table 4), the possibility of dynamic zinc-protein interactions is clear. 


\section{Conclusion}

We have used Density Functional Theory and post-Hartree Fock calculations to investigate $\mathrm{Zn}-\mathrm{S}$ and $\mathrm{Zn}-\mathrm{N}$ bond dissociation processes in classes of $\mathrm{Zn}(\mathrm{SR})_{4}{ }^{2-}$ and $\mathrm{Zn}(\mathrm{Im})(\mathrm{SR})_{3}{ }^{-}$ complexes which are usually used as models of $\mathrm{ZnCys}_{4}$ and $\mathrm{ZnCys}_{3} \mathrm{His}$ protein sites. Our results explain a number of apparently contradictory aspects of the behaviour of such species. The high Lewis acidity of $\mathrm{Zn}^{2+}$ ensures high $\mathrm{Zn}-\mathrm{S}$ (and $\mathrm{Zn}-\mathrm{N}$ ) interaction energies and high stability constants for $\mathrm{ZnCys}_{4}$ (and $\mathrm{ZnHisCys}_{3}$ ) sites, but the presence of three thiolate ligands around the zinc induces kinetic lability in the fourth zinc ligand. This effect is exacerbated in the gas phase by Coulomb repulsion in dianionic $\mathrm{Zn}(\mathrm{SR})_{4}{ }^{2-}$ complexes. In that case, our results illustrate the importance of the overall electronic charge in the zinc complex and the nature of the R substituent on the thermodynamic stability of the complex. The description of $\mathrm{Zn}(\mathrm{SR})_{4}{ }^{2-}$ in terms of resonance structures having one covalent $\mathrm{Zn}-\mathrm{S}$ bond and three ionic $\mathrm{Zn}^{+\cdots} \mathrm{S}^{-}$bonds nicely explains the calculated energetic profile for thiolate dissociation which includes a late transition state. This lability of the fourth ligand in water explains the scarcity of simple anionic zinc complexes in aqueous solutions. Our analysis also implies that the $\mathrm{ZnCys}_{4}$ and $\mathrm{ZnHisCys}_{3}$ cores which are very frequently observed in proteins are metastable toward $\mathrm{Zn}-\mathrm{S}$ and $\mathrm{Zn}-\mathrm{N}$ bond dissociation respectively, and shows that the formation and stability of these sites in proteins is highly dependent upon their environment.

\section{Acknowledgements}

This work was granted access to the High Performance Computing resources of CINES and IDRIS under the allocation 2009-085107 made by GENCI (Grand Equipement National de Calcul Intensif). We thank Dr. Duncan Carmichael for helpful comments on the manuscript. G.F. thanks Dr. Philippe Maître for helpful discussions.

Supporting Information Available: Zn-S bond lengths and binding energies in systems 1a and $2 \mathbf{a}$ as a function of the method of calculation. Cartesian coordinates and absolute electronic, gas-phase, and solvation free energies for all compounds.

\section{Bibliography}

[1] C. Andreini, L. Banci, I. Bertini, A. Rosato, J. Proteome Res. 2006, 5, 196-201.

[2] W. N. Lipscomb, N. Strater, Chem. Rev. 1996, 96, 2375-2433.

[3] B. L. Vallee, D. S. Auld, Biochemistry 1990, 29, 5647-5659.

[4] D. S. Auld, Biometals 2001, 14, 271-313. 
[5] S. Karlin, Z. Y. Zhu, Proc. Natl. Acad. Sci. U. S. A. 1997, 94, 14231-14236.

[6] B. Tamames, S. F. Sousa, J. Tamames, P. A. Fernandes, M. J. Ramos, Proteins 2007, $69,466-475$.

[7] K. Patel, A. Kumar, S. Durani, Biochim. Biophys. Acta 2007, 1774, 1247-1253.

[8] J. H. Laity, B. M. Lee, P. E. Wright, Curr. Opin. Struct. Biol. 2001, 11, 39-46.

[9] W. Maret, J. Anal. At. Spectrom. 2004, 19, 15-19.

[10] T. Bergman, H. Jörnvall, B. Holmquist, B. L. Vallee, Eur. J. Biochem. 1992, 205, 467-470.

[11] W. Maret, Biochemistry 2004, 43, 3301-3309.

[12] A. K. Petros, A. R. Reddi, M. L. Kennedy, A. G. Hyslop, B. R. Gibney, Inorg. Chem. 2006, 45, 9941-9958.

[13] A. R. Reddi, B. R. Gibney, Biochemistry 2007, 46, 3745-3758.

[14] A. Krezel, W. Maret, J. Am. Chem. Soc. 2007, 129, 10911-10921.

[15] G. Tiraboschi, N. Gresh, C. Giessner-Prettre, L. G. Pedersen, D. W. Deerfield, J. Comput. Chem. 2000, 21, 1011-1039.

[16] N. Gresh, J. P. Piquemal, M. Krauss, J. Comput. Chem. 2005, 26, 1113-1130.

[17] E. G. Brandt, M. Hellgren, T. Brinck, T. Bergman, O. Edholm, Phys. Chem. Chem. Phys. 2009, 11, 975-983.

[18] H. Vahrenkamp, Dalton Trans. 2007, 4751-4759.

[19] C. W. Bock, A. K. Katz, J. P. Glusker, J. Am. Chem. Soc. 1995, 117, 3754-3765.

[20] L. Rulisek, J. Vondrasek, J. Inorg. Biochem. 1998, 71, 115-127.

[21] R. R. Roe, Y. P. Pang, J. Mol. Model. 1999, 5, 134-140.

[22] M. Dudev, J. Wang, T. Dudev, C. Lim, J. Phys. Chem. B 2006, 110, 1889-1895.

[23] G. Kuppuraj, M. Dudev, C. Lim, J. Phys. Chem. B 2009, 113, 2952-2960.

[24] M. Pavlov, P. E. M. Siegbahn, M. Sandström, J. Phys. Chem. A 1998, 102, 219-228.

[25] B. J. Mhin, S. Lee, S. J. Cho, K. Lee, K. S. Kim, Chem. Phys. Lett. 1992, 197, 77-80.

[26] K. S. Kim, S. Lee, B. J. Mhin, S. J. Cho, J. Kim, Chem. Phys. Lett. 1993, 216, 309312.

[27] S. Lee, J. Kim, J. K. Park, K. S. Kim, J. Phys. Chem. 1996, 100, 14329-14338.

[28] G. Parkin, Chem. Rev. 2004, 104, 699-767.

[29] A. Jiménez, P. Clapés, R. Crehuet, J. Mol. Model. 2008, 14, 735-746.

[30] M. Koutmos, R. Pejchal, T. M. Bomer, R. G. Matthews, J. L. Smith, M. L. Ludwig, Proc. Natl. Acad. Sci. U. S. A. 2008, 105, 3286-3291.

[31] W. Maret, Y. Li, Chem. Rev. 2009, 109, 4682-4707. 
[32] W. Maret, K. S. Larsen, B. L. Vallee, Proc. Natl. Acad. Sci. U. S. A. 1997, 94, $2233-$ 2237.

[33] C. Jacob, W. Maret, B. L. Vallee, Proc. Natl. Acad. Sci. U. S. A. 1998, 95, 3489-3494.

[34] K. S. Hagen, D. W. Stephan, R. H. Holm, Inorg. Chem. 1982, 21, 3928-3936.

[35] V. Autissier, R. A. Henderson, Inorg. Chem. 2008, 47, 6393-6403.

[36] J. J. Wilker, S. J. Lippard, Inorg. Chem. 1997, 36, 969-978.

[37] J. Seebacher, M. Ji, H. Vahrenkamp, Eur. J. Inorg. Chem. 2004, , 409-417.

[38] J. G. Melnick, G. Zhu, D. Buccella, G. Parkin, J. Inorg. Biochem. 2006, 100, $1147-$ 1154.

[39] U. Heinz, M. Kiefer, A. Tholey, H. W. Adolph, J. Biol. Chem. 2005, 280, 3197-3207.

[40] J. Smirnova, L. Zhukova, A. Witkiewicz-Kucharczyk, E. Kopera, J. Oledzki, A. Wyslouch-Cieszsynska, P. Palumaa, A. Hartwig, W. Bal, Chem. Res. Toxicol. 2008, 21, 386392.

[41] S. Siemann, H. R. Badiei, V. Karanassios, T. Viswanatha, G. I. Dmitrienko, Chem. Commun. 2006, 532-534.

[42] S. I. Gorelsky, L. Basumallick, J. Vura-Weis, R. Sarangi, K. O. Hodgson, B. Hedman, K. Fujisawa, E. I. Solomon, Inorg. Chem. 2005, 44, 4947-4960.

[43] E. I. Solomon, S. I. Gorelsky, A. Dey, J. Comput. Chem. 2006, 27, 1415-1428.

[44] J. L. Larabee, J. R. Hocker, J. S. Hanas, Chem. Res. Toxicol. 2005, 18, 1943-1954.

[45] Q. Liu, M. Golden, M. Y. Darensbourg, N. Farrell, Chem. Commun. 2005, 43604362.

[46] E. Almaraz, Q. A. de Paula, Q. Liu, J. H. Reibenspies, M. Y. Darensbourg, N. P. Farrell, J. Am. Chem. Soc. 2008, 130, 6272-6280.

[47] S. F. Sousa, P. A. Fernandes, M. J. Ramos, Theochem-J. Mol. Struct. 2005, 729, 125129.

[48] D. Picot, G. Ohanessian, G. Frison, Inorg. Chem. 2008, 47, 8167-8178.

[49] E. S. Gruff, S. A. Koch, J. Am. Chem. Soc. 1989, 111, 8762-8763.

[50] Y. Matsunaga, K. Fujisawa, N. Ibi, N. Amir, Y. Miyashita, K. Okamoto, Bull. Chem. Soc. Jpn. 2005, 78, 1285-1287.

[51] D. Swenson, N. C. Baenziger, D. Coucouvanis, J. Am. Chem. Soc. 1978, 100, 19321934.

[52] N. Ueyama, T. Sugawara, K. Sasaki, A. Nakamura, S. Yamashita, Y. Wakatsuki, H. Yamazaki, N. Yasuoka, Inorg. Chem. 1988, 27, 741-747.

[53] A. Silver, S. A. Koch, M. Millar, Inorg. Chim. Acta 1993, 205, 9-14. 
[54] J. Otto, I. Jolk, T. Viland, R. Wonnemann, B. Krebs, Inorg. Chim. Acta 1999, 285, 262-268.

[55] C. P. Rao, J. R. Dorfman, R. H. Holm, Inorg. Chem. 1986, 24, 428-439.

[56] O. Sénèque, E. Bourlès, V. Lebrun, E. Bonnet, P. Dumy, J. M. Latour, Angew. Chem. Int. Ed. 2008, 47, 6888-6891.

[57] O. Sénèque, E. Bonnet, F. L. Joumas, J. M. Latour, Chem. Eur. J. 2009, 15, 47984810.

[58] R. N. Bose, W. W. Yang, F. Evanics, Inorg. Chim. Acta 2005, 358, 2844-2854.

[59] D. Schröder, Angew. Chem. Int. Ed. 2004, 43, 1329-1331.

[60] W. E. Boxford, C. E. H. Dessent, Phys. Chem. Chem. Phys. 2006, 8, 5151-5165.

[61] A. Dreuw, L. S. Cederbaum, Chem. Rev. 2002, 102, 181-200.

[62] L. Pauling, J. Chem. Phys. 1933, 1, 56.

[63] H. Valdes, K. Pluhackova, M. Pitonak, J. Rezac, P. Hobza, Phys. Chem. Chem. Phys. 2008, 10, 2747-2757.

[64] K. E. Riley, B. T. Op't Holt, K. M. Merz Jr, J. Chem. Theory Comput. 2007, 3, 407433.

[65] T. van Mourik, J. Chem. Theory Comput. 2008, 4, 1610-1619.

[66] Y. Zhao, D. G. Truhlar, Theor. Chem. Acc. 2008, 120, 215-241.

[67] Y. Zhao, D. G. Truhlar, J. Chem. Theory Comput. 2008, 4, 1849-1868.

[68] S. F. Sousa, P. A. Fernandes, M. J. Ramos, J. Phys. Chem. A 2007, 111, 1043910452.

[69] T. Ansbacher, H. K. Srivastava, J. M. L. Martin, A. Shurki, J. Comput. Chem. 2010, $31,75-83$.

[70] I. A. Topol, J. R. Casas-Finet, R. Gussio, S. K. Burt, J. W. Erickson, Theochem-J. Mol. Struct. 1998, 423, 13-28.

[71] N. Diaz, D. Suarez, K. M. Merz Jr., Chem. Phys. Lett 2000, 326, 288-292.

[72] T. Dudev, C. Lim, J. Phys. Chem. B 2001, 105, 10709-10714.

[73] S. F. Sousa, P. A. Fernandes, M. J. Ramos, J. Phys. Chem. B 2007, 111, 9146-9152.

[74] S. F. Sousa, E. S. Carvalho, D. M. Ferreira, I. S. Tavares, P. A. Fernandes, M. J. Ramos, J. A. N. F. Gomes, J. Comput. Chem. 2009, 30, 2752-2763.

[75] G. Frison, G. Ohanessian, J. Comput. Chem. 2008, 29, 416-433.

[76] V. M. Rayon, H. Valdes, N. Diaz, D. Suarez, J. Chem. Theory Comput. 2008, 4, $243-$ 256.

[77] E. A. Amin, D. G. Truhlar, J. Chem. Theory Comput. 2008, 4, 75-85. 
[78] A. Sorkin, D. G. Truhlar, E. A. Amin, J. Chem. Theory Comput. 2009, 5, 1254-1265.

[79] G. Frenking, T. Wagener, Transition metal chemistry. In Encyclopedia of computational chemistry ( Ed. : P. V. R. Schleyer), Wiley, Chichester, 1998, 3073-3084.

[80] M. Diedenhofen, T. Wagener, G. Frenking, The accuracy of quantum chemical methods for the calculation of transition metal compounds. In Computational organometallic chemistry ( Ed. : T. Cundari), Marcel Dekker, New York, 2001, 69-121.

[81] W. Koch, M. C. Holthausen, A chemist's guide to density functional theory, 2nd ed.; Wiley-VCH: Weinheim, Germany, 2000.

[82] H. Pesonen, R. Aksela, K. Laasonen, J. Phys. Chem. A 2010, 114, 466-473.

[83] S. Vosko, L. Wilk, M. Nusair, Can. J. Phys. 1980, 58, 1200-1211.

[84] J. P. Perdew, Phys. Rev. B 1986, 33, 8822-8824.

[85] A. D. Becke, Phys. Rev. A 1988, 38, 3098-3100.

[86] M. Sierka, A. Hogekamp, R. Ahlrichs, J. Chem. Phys. 2003, 118, 9136-9148.

[87] R. Ahlrichs, M. Bär, M. Häser, H. Horn, C. Kölmel, Chem. Phys. Lett. 1989, 162, 165-169.

[88] A. Schäfer, H. Horn, R. Ahlrichs, J. Chem. Phys. 1992, 97, 2571-2577.

[89] F. Weigend, R. Ahlrichs, Phys. Chem. Chem. Phys. 2005, 7, 3297-3305.

[90] F. Weigend, Phys. Chem. Chem. Phys. 2006, 8, 1057-1065.

[91] A. P. Scott, L. Radom, J. Phys. Chem. 1996, 100, 16502-16513.

[92] C. T. Lee, W. T. Yang, R. G. Parr, Phys. Rev. B 1988, 37, 785-789.

[93] A. D. Becke, J. Chem. Phys. 1993, 98, 5648-5652.

[94] F. Weigend, M. Häser, H. Patzelt, R. Ahlrichs, Chem. Phys. Lett. 1998, 294, 143-152.

[95] S. Grimme, J. Comput. Chem. 2004, 25, 1463-1473.

[96] S. Grimme, J. Comput. Chem. 2006, 27, 1787-1799.

[97] O. Christiansen, H. Koch, P. Jorgensen, Chem. Phys. Lett. 1995, 243, 409-418.

[98] C. Hättig, F. Weigend, J. Chem. Phys. 2000, 113, 5154-5161.

[99] A. Hellweg, C. Hättig, S. Höfener, W. Klopper, Theor. Chem. Acc. 2007, 117, 587597.

[100] A. Klamt, G. Schüürmann, J. Chem. Soc., Perkin Trans. 2 1993, 5, 799-805.

[101] A. E. Reed, F. Weinhold, J. Chem. Phys. 1985, 83, 1736-1740.

[102] A. E. Reed, R. B. Weinstock, F. Weinhold, J. Chem. Phys. 1985, 83, 735-746.

[103] A. E. Reed, L. A. Curtis, F. Weinhold, Chem. Rev. 1988, 88, 899-926.

[104] M. J. Frisch, G. W. Trucks, H. B. Schlegel, G. E. Scuseria, M. A. Robb, J. R. Cheeseman, J. A. Montgomery Jr., T. Vreven, K. N. Kudin, J. C. Burant, J. M. Millam, S. S. 
Iyengar, J. Tomasi, V. Barone, B. Mennucci, M. Cossi, G. Scalmani, N. Rega, G. A. Petersson, H. Nakatsuji, M. Hada, M. Ehara, K. Toyota, R. Fukuda, J. Hasegawa, M. Ishida, T. Nakajima, Y. Honda, O. Kitao, H. Nakai, M. Klene, X. Li, J. E. Knox, H. P. Hratchian, J. B. Cross, C. Adamo, J. Jaramillo, R. Gomperts, R. E. Stratmann, O. Yazyev, A. J. Austin, R. Cammi, C. Pomelli, J. W. Ochterski, P. Y. Ayala, K. Morokuma, G. A. Voth, P. Salvador, J. J. Dannenberg, V. G. Zakrzewski, S. Dapprich, A. D. Daniels, M. C. Strain, O. Farkas, D. K. Malick, A. D. Rabuck, K. Raghavachari, J. B. Foresman, J. V. Ortiz, Q. Cui, A. G. Baboul, S. Clifford, J. Cioslowski, B. B. Stefanov, G. Liu, A. Liashenko, P. Piskorz, I. Komaromi, R. L. Martin, D. J. Fox, T. Keith, M. A. Al-Laham, C. Y. Peng, A. Nanayakkara, M. Challacombe, P. M. W. Gill, B. Johnson, W. Chen, M. W. Wong, C. Gonzalez, J. A. Pople, Gaussian 03, revision C.02, 2003, Gaussian, Inc, Wallingford CT.

[105] K. B. Wiberg, Tetrahedron 1968, 24, 1083-1096.

[106] P. Sarada, D. Carmichael, G. Bouchoux, S. Bourcier, G. Frison, Unpublished results.

[107] G. Frenking, N. Fröhlich, Chem. Rev. 2000, 100, 717-774.

[108] P. M. W. Gill, L. Radom, Chem. Phys. Lett. 1987, 136, 294-298.

[109] P. M. W. Gill, L. Radom, Chem. Phys. Lett. 1988, 147, 213-218.

[110] B. de Courcy, J. P. Piquemal, N. Gresh, J. Chem. Theory Comput. 2008, 4, 16591668.

[111] B. de Courcy, N. Gresh, J. P. Piquemal, Interdiscip. Sci. Comput. Life Sci. 2009, 1, 55-60.

[112] D. Fabris, J. Zaia, Y. Hathout, C. Fenselau, J. Am. Chem. Soc. 1996, 118, 1224212243.

[113] D. Fabris, Y. Hathout, C. Fenselau, Inorg. Chem. 1999, 38, 1322-1325.

[114] T. Simonson, N. Calimet, Proteins 2002, 49, 37-48.

[115] G. Frison, G. Ohanessian, Phys. Chem. Chem. Phys. 2009, 11, 374-383. 